\title{
Law and the International Community: Looking Into the (Post-COVID-19) Future
}

\author{
Nicky Jones \\ \{Nicky.Jones@usq.edu.au\} \\ ${ }^{1}$ University of Southern Queensland, Australia
}

\begin{abstract}
This article aims to discuss the global legal challenges in the post-COVID 19. One of the most visible challenges is the human rights challenge created by the COVID-19 restrictions has been the focus of serious debate in Australia. In the state of Queensland, legislation enacted on 18 March 2020 empowers the Chief Health Officer ('CHO') and other emergency officers to implement social distancing measures, including arranging mass gatherings, isolating or quarantining people suspected or known to have been exposed to COVID -19. These restrictions affect movement and gatherings across communities in contexts such as schools, higher education, hospital, court proceedings, family gatherings, sporting and community events, public entertainment, tourism, travel and vacations. There are many reasons why governments limit the human rights of its citizens. The challenge for society and government is to ensure that any restrictions on human rights are reasonable and justifiable.
\end{abstract}

Keywords: Human Rights, Chief Health Officer, Queensland. Pandemic Covid-19

\section{Introduction}

I had originally intended to talk about globalisation and the international community with reference to this auspicious year of 2020. This year seemed to be an appropriate time to look around with '2020 vision'.[1] and to consider some questions about the role of public international law in a globalised world. An important threshold question might be: what is globalisation? What does it represent when we are talking about the development of the law that is expected to address its various problems? Although the term globalisation is commonly used, it has different meanings for different people and entities in the international community. I am reassured by legal scholar Professor Wolfgang Friedmann's observation that 'over thousands of years the most powerful minds of all nations have been unable to agree on a universal definition of law'.[2] Although I don't believe that Professor Friedmann turned his attention to the term 'globalisation', I am confident that he would have reached a similar conclusion if he had.

The current coronavirus crisis has now raised particular questions in relation to globalisation. Academic and media commentary currently fluctuates between warning that COVID-19 means the end of globalisation and predicting that the virus highlights the importance of globalisation.[3] As we know, the coronavirus pandemic has shut down many of the everyday activities of a globalised world: international travel has slowed or stopped, countries have closed their borders, domestic and international tourism have ground to a halt, foreign workers and students have returned home and local populations are in lockdown to an extent that would have been unimaginable a year ago. The nation State has never seemed more important or omnipotent, with countries enacting wide-ranging restrictions in response to the 
pandemic. Domestic commercial activity and economies have declined, jobs are cut and unemployment is rising in many countries, national laws and regulations are prioritising nationals over foreigners and 'globalisation has imploded.'[4]

My paper will start by discussing the novel coronavirus disease, now commonly called COVID-19, and will consider the public health restrictions that have been imposed to respond to the COVID-19 pandemic, with reference to human rights law, in my jurisdiction of Queensland. In this discussion I will mention briefly the challenges to global governance that the COVID-19 crisis has brought to prominence.

\section{Result and Discussions}

\subsection{Coronavirus and COVID-19 Restrictions}

In late December 2019, international media reported the rapid spread of a novel coronavirus disease, starting in Wuhan City in the People's Republic of China.[5] There was increasing international awareness of its transmission in China and into other countries, including Australia, throughout January 2020.

On 29 January 2020, my home state of Queensland become the first state in Australia to declare a public health emergency due to the outbreak of COVID-19 in China, its pandemic potential due to cases spreading to other countries and the public health implications within Queensland.[6] The public health emergency order was declared for all of Queensland for seven days but has been extended several times.[7]

On 30 January 2020, the Director-General of the World Health Organisation ('WHO') declared that COVID-19 was a public health emergency of international concern. On 11 March 2020, the Director-General declared that COVID-19 could be characterised as a global pandemic. Since then, data collected by the WHO underpin the declaration: as at 26 June 2020, the number of confirmed cases worldwide sat at 9.8 million across 216 countries, with almost 500,000 confirmed deaths. [8] In the current pandemic, there is an important role to play for a central agency such as the WHO, which can impartially share public health information, coordinate equipment and expertise and advise States on the best responses to the coronavirus crisis.

States must work with international organisations such as the WHO to guide and make decisions that will affect the health of their populations. In its founding Constitution, the WHO urged all States to commit to 'the health of all peoples', which is 'fundamental to the attainment of peace and security' and depends on 'the fullest co-operation of individuals and States.' The Constitution also offers a salient warning to States who adopt isolationism and exclusionary policies: 'Unequal development in different countries in the promotion of health and control of disease, especially communicable disease, is a common danger.' [9]

There is also an important part to play for individual nations in the international community. States must be seen to take responsible and intelligent action to restrict COVID-19 transmission, and to share information and resources with neighbouring States to assist with their responses to the coronavirus. Over the past few months, we have seen that some States responded rapidly to early warnings about COVID-19 by, for example, closing their borders, declaring a national public health emergency, imposing social distancing, testing early and often and preparing personal protective equipment. Jurisdictions that acted early, like Queensland and countries such as South Korea, Thailand and Vietnam,[10] Georgia and Costa Rica,[11] appear to have had better public health outcomes. The Indian state of Kerala commenced intensive public health interventions in January which have set it up well for the challenges that followed.[12] As is apparent from COVID-19 infection and transmission rates in the USA, States that dismissed global warnings about COVID-19 by the WHO and other expert bodies because such messages were unpopular or inconvenient, or called for a cooperative response,[13] have not fared well.[14] 
Along with reports of nationalist sentiment and protectionism,[15] the pandemic has also generated international cooperation. For example, scientists and medical professionals have collaborated to identify the virus' genome sequence and share information on how the virus affects (and infects) the human body.[16] Former senior Australian bureaucrat Jane Halton heads up the Coalition for Epidemic Preparedness Innovations, an international public health coalition that is now spearheading the global race to develop - and fairly distribute - a vaccine for COVID-19.[17]

\subsection{Restrictions and Human Rights}

The human rights challenges created by the COVID-19 restrictions have been the focus of much debate in Australia. In recent months, restrictions on movements and gatherings have been imposed by the different states and territories, resulting in a patchwork of laws restricting individual and commercial activities in response to perceived levels of risk in the different jurisdictions. In my state of Queensland, legislation enacted on 18 March 2020 empowered the Chief Health Officer ('CHO') and other emergency officers to implement social distancing measures, including regulating mass gatherings, isolating or quarantining people suspected or known to have been exposed to COVID-19 and protecting vulnerable populations such as the elderly.[18] From 19 March 2020, the CHO issued public health directions every day or couple of days in relation to different topics including trading hours, gatherings, aged care, the upcoming local government elections, border restrictions, non-essential business closure, corrective services facilities, and school and early childhood service exclusion. On 2 April 2020, the CHO issued the comprehensive Home Confinement, Movement and Gathering Direction 'to assist in containing, or to respond to, the spread of COVID-19 within the community.' The Home Confinement, Movement and Gathering Direction imposed home confinement except for 14 'permitted purposes' and limited gatherings in private residences and commercial premises. These restrictions affected movement and gatherings across the community in contexts such as school, tertiary education, work, hospitality, court proceedings, family get-togethers, sporting and community events, public entertainment, tourism, travel and holidays. The direction applied from 2 April 2020 until 'the end of the declared public health emergency'.[19]

The CHO's reasons for making the public health directions that imposed the COVID-19 restrictions in Queensland were obvious to most people who followed the news. In addition, the Queensland government announced the restrictions in numerous public and media statements and the Health Minister explained their context, purpose, scope and limited duration in the extrinsic materials that supported the amending legislation. In Queensland, these restrictions raised important questions about human rights. The questions were particularly apt because last year the Queensland Parliament enacted new human rights legislation. The Human Rights Act 2019 (Qld) was proclaimed into force in its entirety from 1 January 2020 - just in time to apply to the COVID-19 restrictions.

The Human Rights Act 2019 (Qld) protects 23 human rights, mostly civil and political rights but also two economic, social and cultural rights, which makes it quite ground-breaking for a Western liberal and common law jurisdiction. The Act also imposes specific duties and obligations on all branches of government: the executive plays its part through administrative decision-making and policy development, the legislature scrutinises and passes legislation, and the judiciary interprets laws and adjudicates rights. Not surprisingly, the COVID-19 restrictions breached a number of human rights. The most obvious of these was the right to freedom of movement, protected under s 19 of the Human Rights Act 2019 (Qld), although other rights were also restricted, notably rights to privacy, peaceful assembly, freedom of expression, take part in public life, liberty, and others.[20] Section 19 provides that every person who is lawfully in Queensland has the right to move freely within the state, and to enter and leave Queensland, and 
has the freedom to choose where to live. The right to freedom of movement applies to all people lawfully in Queensland and means that public entities cannot act in a way that would unduly restrict people's freedom of movement. In addition to protecting human rights, international human rights law provides that many human rights may be subject to limitations in prescribed circumstances.[21] Section 13 of the Human Rights Act 2019 (Qld) provides that the 23 human rights may be subject under law to reasonable limits that can be demonstrably justified in a free and democratic society in order to protect the rights of others or important public policy issues. The provision sets out factors that must be considered when deciding whether a limit on a right is reasonable and justifiable.

This paper does not have the scope to assess the threshold questions and the permissible limitations test that must be satisfied before a conclusion may be reached about whether a human rights limitation is reasonable and demonstrably justified under the Human Rights Act 2019 (Qld). However, a broad assessment of the relevant provisions suggests that the COVID-19 restrictions are not in breach of Queensland law. The restrictions may be regarded as emergency measures that are unavoidable, specific to the COVID-19 public health emergency and of finite duration. On balance, they may be reasonable and justifiable limitations on human rights in the current global coronavirus pandemic. The detailed explanations of the purpose, scope and duration of the COVID-19 restrictions, together with the national and international circumstances of the COVID-19 pandemic, brought what would otherwise be government breaches of human rights within the permitted limitations provided under s 13 of the Human Rights Act 2019 (Qld).

The non-governmental organisation Human Rights Watch advises that the scale and severity of the COVID-19 pandemic' indicate that it is a sufficiently significant public health threat to justify restrictions on certain human rights 'such as those that result from the imposition of quarantine or isolation limiting freedom of movement.' Human Rights Watch also warns that governments should not impose overly broad restrictions that do not meet these criteria and recommends 'careful attention to human rights such as non-discrimination and human rights principles such as transparency and respect for human dignity'.[22] There are many reasons why governments restrict the human rights of their populations. The challenge for communities and governments alike is to ensure that any restrictions on human rights are indeed reasonable and justifiable, as required under the balancing exercise set out in s 13 of Queensland's Human Rights Act 2019.

The Human Rights Act 2019 (Qld) does not unreasonably bind the government or public entities in their acts and decisions. Its legislative objects are to encourage dialogue about human rights and to develop a culture in the Queensland public sector that respects and promotes human rights. Importantly, the Human Rights Act 2019 does not overturn parliamentary supremacy. This means that the Queensland Parliament may override it or even amend it into insignificance, although undoubtedly at a political cost. International human rights law offers a salutary reminder to communities as well as governments of its overarching purpose: to protect people against government mistreatment and to restrain governments from acting in ways that harm people's human rights.

\section{Conclusions}

The COVID-19 pandemic is a truly global problem that has confronted all countries around the world at the same time - an urgent problem that calls for global solutions.[23] Yet the United Nations' global health agency has not been without critics for its role during this and previous pandemics, with the US President being one of its most vocal critics. Australia's Prime Minister Scott Morrison has promised a three-point plan to 'reform' the governance of the WHO, create an independent review organisation to examine its performance in global health calamities such as the current COVID-19 pandemic. Most controversially, the PM wants to empower the WHO 
to send teams of investigators into countries to determine the factors behind disease outbreaks. These investigators, he argues, could be similar to weapons inspectors deployed to verify disarmament programs.[24]

The idea of pandemic police raises some interesting issues in the context of international law. Few international organisations have the power to unilaterally enter a State to undertake an investigation. In the field of human rights, many States have issued standing invitations to the United Nations Human Rights Council to allow independent human rights experts to enter to assess compliance, but many have not. Even in the highly developed European human rights system, only one treaty - the European Torture Conventiom[25] - mandates States to permit visits by independent experts.[26] Professor Alison Duxbury of the University of Melbourne has flagged objections to the idea, noting that weapons inspectors gain their powers from treaties that address threats to international peace and security. Although the WHO Constitution recognises that the health of all peoples is fundamental to the attainment of peace and security, the Security Council has only once identified a pandemic as such a threat: the Ebola outbreak in conflictridden West Africa in 2014.[27]

In the current circumstances, the idea that the WHO could turn into "the policeman [of] global health' is likely to remain the 'dream [that] will never happen', as former WHO Legal Counsel Gian Luca Burci has observed.[28] The COVID-19 pandemic has indeed been global in its impact, yet the legal responses, while based on the advice of an international body, have remained intensely local. The pandemic reminds us not just of how interconnected the modern world has become but of how important the role of each and every nation State is in securing a world that is safe for all of its citizens. Whether or not the global legal frameworks on public health are still fit for purpose for an effective global public health response is likely to be the subject of an intense and ongoing debate.

\section{References}

[1] English expression meaning 'to see clearly' because eye doctors assess normal vision as '20/20'

[2] Friedmann, Wolfgang. Legal Theory (Stevens \& Sons, $2^{\text {nd }}$ ed, 1949) 422.

[3] Elliott, Larry 'Of course there's a globalisation backlash. It has failed billions of people',

The Guardian (13 $\quad$ February 2020)

<https://www.theguardian.com/commentisfree/2020/feb/13/globalisation-backlash-openmarkets-borders-climate-populism-coronavirus>; The University of South Australia, 'Globalisation the cause and the cure for COVID-19' (Media release, 7 May 2020) $<$ https://www.unisa.edu.au/Media- Centre/Releases/2020/globalisation-the-cause-and-thecure-for-covid-19>; 'Has covid-19 killed globalisation?' The Economist (14 May 2020) $<$ https://www.economist.com/leaders/2020/05/14/has-covid-19-killed- globalisation>; Angel Alcalde \& Jose M. Escribano, 'Will COVID-19 end globalisation?' (16 May 2020) The University of Melbourne <https://pursuit.unimelb.edu.au/articles/will-covid-19-endglobalisation>; Steven A Altman, 'Will Covid-19 Have a Lasting Impact on Globalization?' Harvard Business Review (20 May 2020) <https://hbr.org/2020/05/will-covid-19-have-alasting-impact-on-globalization>.

[4] Grenville, Stephen, 'Globalisation' (no date), Lowy Institute <https://interactives.lowyinstitute.org/features/covid19/issues/globalisation>.

[5] Agence France-Presse, 'Coronavirus timeline: from Wuhan to Washington state', The Guardian (23 January 2020) <https://www.theguardian.com/science/2020/jan/23/coronavirustimeline-from-wuhan-to-washington- state>.

[6] The Minister for Health and Minister for Ambulance Services declared a public health emergency under s 319 of the Public Health Act 2005 (Qld). 
[7] 'Public Health Emergency Order' 383(25) Queensland Government Gazette 97 (31 January 2020). The declared public health emergency for COVID-19 was originally due to expire on 6 February 2020 but regulations subsequently extended it to 12 February 2020, 19 February 2020, 19 May 2020 and 17 August 2020: see s 2 of the Public Health (Extension of Declared Public Health Emergency-Coronavirus (2019-nCoV)) Regulation 2020 (Qld), Public Health (Further Extension of Declared Public Health Emergency-Coronavirus (2019nCov)) Regulation 2020 (Qld), Public Health (Further Extension of Declared Public Health Emergency-Coronavirus (2019-nCoV)) Regulation (No. 2) 2020 (Qld) and Public Health (Further Extension of Declared Public Health Emergency-COVID-19) Regulation (No. 3) 2020 (Qld) respectively.

[8] World Health Organisation, 'Coronavirus disease (COVID-19) outbreak situation' (26 June 2020) 〈https://www.who.int/emergencies/diseases/novel-coronavirus-2019>.

[9] Constitution of the WHO, opened for signature on 22 July 1946 (entered into force on 7 April 1948).

[10] Ratcliffe, Rebecca. 'Thailand, Malaysia, Vietnam... How some countries kept Covid at bay', The Guardian (14 June 2020) <https://www.theguardian.com/world/2020/jun/14/thailand-malaysia-vietnam-how-somecountries-kept-covid-at-bay>.

[11] Taylor, Adam \& Berger, Miriam, 'When it comes to coronavirus response, superpowers may need to study smaller nations', The Washington Post (17 May 2020) <https://www.washingtonpost.com/world/2020/05/16/when-it-comes-coronavirus-responsesuperpowers-may- need-study-smaller-nations>.

[12] Kurian, Oommen C. 'How the Indian state of Kerala flattened the coronavirus curve', The Guardian (21 April <https://www.theguardian.com/commentisfree/2020/apr/21/kerala-indian-state-flattenedcoronavirus- curve>; Saju Mathew, 'The Indian state that got its Covid-19 response right' (27 June 2020), CNN <https://edition.cnn.com/2020/06/27/opinions/kerala-coronavirus-strategysuccess-mathew/index.html $>$.

[13] Walters, Joanna et al, 'Trump calls WHO's global death rate from coronavirus "a false number", The Guardian (6 March 2020) <https://www.theguardian.com/world/2020/mar/05/trump-coronavirus-who-global- death-ratefalse-number>.

[14] Daly, Tom Gerald, 'How COVID-19 is hitting some democracies harder than others' (3 June 2020) The University of Melbourne <https://pursuit.unimelb.edu.au/articles/how-covid19-is-hitting-some-democracies- harder-than-others $>$; Andrew Liu, 'Blaming China for coronavirus isn't just dangerous. It misses the point', The Guardian (10 April 2020) <https://www.theguardian.com/commentisfree/2020/apr/10/blaming-china- coronaviruspandemic-capitalist-globalisation-scapegoat>.

[15] Tsang ,Amie, 'E.U. Seeks Solidarity as Nations Restrict Medical Exports' The New York Times (7 March 2020) < https://www.nytimes.com/2020/03/07/business/eu-exports-medicalequipment.html>; Lynsey Jeffery, 'German, French Officials Accuse US Of Diverting Supplies’ (4 April 2020), NPR <https://www.npr.org/2020/04/04/827321294/german-frenchofficials-accuse-u-s-of-diverting-supplies $>$.

[16] Venaik, Sunil, 'Coronavirus hasn't killed globalisation - it proves why we need it', The Conversation (6 May 2020) <https://theconversation.com/coronavirus-hasnt-killedglobalisation-it-proves-why-we-need-it-135077>.

[17] Hatchett, Richard, 'COVAX: Ensuring fair allocation of a COVID-19 vaccine' (26 June 2020), CEPI <https://cepi.net/news_cepi/covax-ensuring-fair-allocation-of-a-covid-19vaccine>; Coalition for Epidemic Preparedness Innovations, 'CEPI's response to COVID-19', CEPI <https://cepi.net/covid-19>; see also World Economic Forum, 'The Forum's COVID Action Platform: Over 1,000 organisations are working together in response to the pandemic', 
(6 May 2020) <https://www.weforum.org/our-impact/the-forum-s-covid-action- platformover-1-000-organizations-are-working-together-in-response-to-the-pandemic>.

[18] Statement of Compatibility, Public Health and Other Legislation (Public Health Emergency) Amendment Bill 2020 (Qld) 2.

[19] Chief Health Officer, Queensland Health, Home Confinement, Movement and Gathering Direction: Direction from Chief Health Officer in accordance with emergency powers arising from the declared public health emergency (2 April 2020). This direction was updated until its last version was replaced by eased restrictions in the Movement and Gathering Direction which commenced on 1 June 2020: see <https://www.health.qld.gov.au/systemgovernancellegislation/cho-public-health-directions-under-expanded- public-health-actpowers $>$.

[20] Statement of Compatibility, Public Health and Other Legislation (Public Health Emergency) Amendment Bill 2020 (Qld) 16-20.

[21] Some international human rights provisions set out their own restrictions: for example, Article 12 of the International Covenant on Civil and Political Rights, opened for signature 19 December 1966, 999 UNTS 171 (entered into force 23 March 1976) ('ICCPR') provides that the right to liberty of movement may be subject to restrictions which are provided by law, necessary to protect national security, public order, public health or morals, or the rights and freedoms of others). Article 4 of the ICCPR also provides that in times of 'public emergency which threatens the life of the nation', many (although not all) human rights may be suspended 'to the extent strictly required by the exigencies of the situation'.

[22] Human Rights Watch, 'Human Rights Dimensions of COVID-19 Response' (19 March 2020) <https://www.hrw.org/news/2020/03/19/human-rights-dimensions-covid-19-response> .

[23] Venaik, Sunil, 'Coronavirus hasn't killed globalisation - it proves why we need it', The Conversation (6 May 2020) <https://theconversation.com/coronavirus-hasnt-killedglobalisation-it-proves-why-we-need-it-135077>.

[24] Farr, Malcolm. 'Australian PM pushes for WHO overhaul including power to send in investigators', The Guardian (22 April 2020) <https://www.theguardian.com/australianews/2020/apr/22/australian-pm-pushes-for- $\quad$ who-overhaul-including-power-to-send-ininvestigators>.

[25] European Convention for the Prevention of Torture and Inhuman or Degrading Treatment or Punishment, opened for signature 26 November 1987, ETS No 126 (entered into force 1 February 1989).

[26] Duxbury, Alison, 'The World Health Organization as pandemic police?' (29 May 2020) The University of Melbourne <https://pursuit.unimelb.edu.au/articles/the-world-healthorganization-as-pandemic-police>.

[27] SC Res 2177, UN Doc S/RES/2177 (18 September 2014); Alison Duxbury, 'The World Health Organization as pandemic police?' (29 May 2020) The University of Melbourne <https://pursuit.unimelb.edu.au/articles/the- world-health-organization-as-pandemic-police〉.

[28] Burci, Gian Luca, 'What's law got to do with COVID-19?' webinar (21 April 2020), Global Health Centre, Graduate Institute of Geneva <https://graduateinstitute.ch/covidwebinar-law>. 